\title{
REVIEW
}

\section{Contrasting micro- and macro-nutrient nourishment of the ocean}

\author{
Ian S. F. Jones* \\ Ocean Technology Group, University of Sydney, Sydney, New South Wales 2006, Australia
}

\begin{abstract}
There have been suggestions that an increase in the productivity of the ocean would store more carbon in the ocean organic carbon cycle, as well as enhancing the higher trophic levels of the marine food web. Proposals have included fertilisation of regions low in one or more of nitrogen, phosphorus or iron, the latter being termed a micronutrient. Iron is available from mining, phosphorus from mining or artificially induced upwelling, and the provision of nitrogen involves using either cyanobacteria, the Haber-Bosch process or artificially induced upwelling. All these fertilisation methods can be effective in locally increasing new primary production, but the global impact varies because of iron scavenging, nutrient stealing or the role of regenerative primary production. Examination of these concepts leads to the conclusion that macronutrient nourishment supplied by the Haber-Bosch process is an attractive approach for slowing climate change and increasing marine productivity. The carbon storage capacity of nitrogen fertilisation appears to be limited by the supply of phosphorus to support additional new primary production.
\end{abstract}

KEY WORDS: Climate change $\cdot$ Ocean carbon cycle $\cdot$ Ocean nourishment $\cdot$ Primary production

\section{INTRODUCTION}

If the primary production of the ocean were to be increased as mankind has enhanced the primary productivity of agricultural lands, there could be benefits for both climate management and marine protein production according to some scientists. Phytoplankton, the dominant component of marine new primary production, takes carbon from the surface ocean to create organic material. This provides energy for higher trophic levels in the marine food web and also produces a rain of carbon to the deep ocean, where it is isolated from the atmosphere. A fraction of the carbon falls to the sea floor.

Primary production on the land is often limited by the supply of nutrients and this limitation is relieved by the addition of fertiliser. Over $100 \mathrm{Mt}\left(10^{8} \mathrm{t}\right)$ of nitrogen fertiliser is delivered to the land worldwide each year in order to increase the primary production, and some of this fertiliser reaches the ocean as runoff. In the upper ocean, phytoplankton captures carbon dioxide and converts it to organic carbon, in a partial analogy of trees. Turbulent fluxes of carbon dioxide between the ocean and the atmosphere resupply the inorganic carbon. Due to senescence and predation of the planktonic biomass, such carbon sinks to the deep ocean. If this process can be enhanced, carbon dioxide from the atmosphere could be stored in the deep-ocean organic carbon cycle, mitigating the threat of rapid climate change. Concern about climate change sparked the Royal Society of London review of global-scale actions available to manage climate change (Shepherd 2009). The review considered ocean fertilisation as an example of carbon dioxide removal from the atmosphere.

The risks from climate change and the need for more protein as the human population rises have prompted calls to increase the primary production of the world's oceans. In this review, I will focus on fertilisation by any of 3 nutrients: nitrogen, phosphorus and iron. The 
first two are known as macronutrients while iron is classified as a micronutrient (also known as a trace nutrient). Martin et al. (1990a) first brought attention to the concept of providing a limiting trace nutrient to certain regions of the ocean to increase productivity. A number of culture bottle studies, mesoscale ocean experiments and ocean circulation models have clarified the role that nutrient addition might have on ocean productivity.

Increased productivity in the form of new primary production will enhance the flow of energy through the marine food chain. Most of the anthropogenic activity in the ocean consists of hunting and gathering, together with the transport of goods and people. Fortunately, the low level of this usage means there is little foregone opportunity (opportunity cost) in making increased use of the ocean for extra food production, in contrast to attempting more intense farming on land. There are many who see an aesthetic value in undisturbed vast barren expanses of ocean. This view must be weighed against the need of malnourished humans for economical protein. Humans have already exceeded the sustainable fish catch for the large members of the marine ecosystem, which is a significant disturbance to the ocean ecology. We have now started fishing down the food chain (Pauly et al. 2000). Is there a way to have both an adequate amount of protein for the poor and also a sustainable ocean ecology?

Recent reviews consider the strategy of large-scale iron fertilisation of the oceans for increasing productivity (de Baar et al. 2005, Boyd 2008), but no review has contrasted ocean fertilisation using the micronutrient iron with other strategies to provide macronutrients. While the present review focuses on such a contrast, it does not treat the broader issues of the manipulation of oceans as this has recently been discussed by Jones \& Young (2009) and Johnston et al (1999). Costs of ocean fertilisation are an important consideration but are not compared here. Readers are instead referred to Boyd (2008) and Shoji \& Jones (2001).

\section{OCEAN CARBON CYCLE}

At the heart of the dynamics of the ocean is the flow of energy and materials. The vertical circulation of the waters in the ocean basins transports nutrients in a continuous cycle. The strong density gradient of the seasonal thermocline inhibits vertical exchange between the ocean surface mixed layer and the ocean abyss. The solar energy input to the photic zone supports the conversion of inorganic nutrients to organic matter in a process known as primary production. Assuming upwelling of $13 \mathrm{~m} \mathrm{yr}^{-1}$ (Broecker \& Peng 1982), surface water remains at the ocean surface for a decade before it is subducted, or mixed, below the bottom of the seasonal thermocline. While in the photic zone and above the thermocline, the nutrients in the water contributes first to new primary production, and then some of the organic matter is decomposed (regenerated) to support further primary production. Eventually the water is subducted below the surface layer and starts its long journey through the deep ocean. When this water again enters the photic zone after its cycle through the deep ocean, its nutrients have been replenished by the rain of organic matter from the surface ocean.

Clearly, nutrients limit the capacity of the marine food chain to produce protein. The limited supply of nutrients that enters the surface ocean restricts the new primary production, on which the regenerated production and secondary production depend. Tyrrell (1999) and many others discuss which nutrient in the surface ocean is limiting new primary production. Locally, new primary production may be limited by one or more elements that often include nitrogen, phosphorus or iron. As the surface water is advected by the large ocean gyres, new inputs of iron or reactive nitrogen from the atmosphere can relieve the limitation. Rivers are also supplying new reactive nitrogen as a result of the fertilisation of agricultural lands. Nutrients that are carried below the photic zone before they can participate in the generation of primary production and the flow of energy to higher trophic levels are in a sense wasted. Each natural assemblage of phytoplankton that performs the new primary production has different nutrient needs. Only certain organisms, called diazotrophs, can break the diatomic nitrogen bond and directly use nitrogen gas, $\mathrm{N}_{2}$, which is available in vast quantities in the atmosphere. Diazotrophs are thus able to increase the supply of nitrogen for regenerated production. As diazotrophs need phosphorus, this suggests that on time scales of centuries, phosphorus might be the ultimate limiting nutrient in the sea.

Phytoplankton photosynthetically converts dissolved inorganic material to organic particulate matter, which is strongly influenced by gravity. Senescent organic matter sinks below the surface ocean and is said to be exported. The energy needed for photosynthesis in the ocean comes from the sun. Solar energy is transformed, with the aid of chlorophyll, into chemical energy. While the level of sunlight regulates the rate of primary production on the time scale of a day, it is the availability of nutrients over most of the ocean that limit the growth of phytoplankton on time scales of months.

Some of the senescent phytoplankton that has grown in the surface ocean sinks below the base of the surface mixed layer before it can be remineralised back to their inorganic components. The fraction of detritus that is 
broken down in the seasonal thermocline is available to the photic zone after winter deepening of the surface mixed layer. While the term 'export' is generally used rather loosely, I will use the term 'deep export' to mean the transport of material deeper than the top of the permanent thermocline. The winter mixed layer depth, with the exception of portions of the polar ocean, is less than 200 m (de Boyer Montegut et al. 2004). Most of the exported matter is remineralised as it falls through the deep ocean and is not available to the photic zone for many decades. The exported biomass is approximately in the Redfield ratio of C:N:P of 106:16:1, a robust average relationship for biological production on a longterm, large-scale basis. As these elements are advected by the deep ocean currents, they, with the major exception of the micronutrient iron, stay in a constant ratio. Once they enter the photic zone again, they bring with them the carbon that was exported years earlier. When the concentration of dissolved carbon exceeds that needed to be in equilibrium with the atmosphere, the excess carbon moves to the atmosphere as carbon dioxide. The nutrients are reused in new primary production and the process of cycling carbon through the deep ocean continues. Therefore to the first order, steadystate photosynthesis, which drives the organic carbon cycle, does not lead to changes in the quantity of carbon stored in the ocean.

Bienfang \& Ziemann (1992) estimated that new primary production is approximately 7.4 Gt C $\mathrm{yr}^{-1}$. More recent estimates by Laws et al. (2000) provide a value

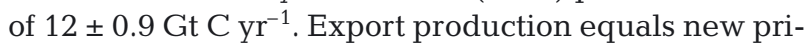

mary production on a yearly time scale (Gordon et al. 1997). Thus these values for new primary production also provide estimates of values for export of carbon from the surface ocean.

The global ocean models studied by Najjar et al. (2007) indicated a mean export of particles and dis-

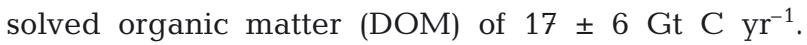
Assuming the exported matter is in the Redfield ratio (by weight), $\mathrm{C}: \mathrm{N}$ of $(106 \times 12):(16 \times 14)$, this export process consumes $17 \div 5.7=3 \mathrm{Gt}\left(3 \times 10^{12} \mathrm{~kg}\right) \mathrm{N} \mathrm{yr}^{-1}$. This is more cycling nitrogen than the $1.55 \mathrm{Gt} \mathrm{N} \mathrm{yr}^{-1}$ proposed by Gruber (2008). If we assume the majority of this nitrogen is upwelled, and since Gruber (2008) proposes a representative nitrogen concentration in the deep ocean is $31 \mu \mathrm{M}\left(\mathrm{M}=\mathrm{mol} \mathrm{l}^{-1}\right)$ or $434 \times 10^{-6} \mathrm{~kg} \mathrm{~N}$ $\mathrm{m}^{-3}$, this implies a water upwelling volume of $\left(3 \times 10^{12}\right)$ $\div\left(434 \times 10^{-6}\right)=6.9 \times 10^{15} \mathrm{~m}^{3} \mathrm{yr}^{-1}$. This suggests that the organic carbon cycle is driven by a vertical flow of 220 Sverdrup $\left(\mathrm{Sv}_{;} 10^{6} \mathrm{~m}^{3} \mathrm{~s}^{-1}\right)$, a substantially higher upwelling rate than that used by Sarmiento \& Gruber (2006) in their 2 box model. They suggested export fluxes closer to $10 \mathrm{Gt} \mathrm{C} \mathrm{yr}^{-1}$ as more appropriate, implying an upwelling flow of $129 \mathrm{~Sv}$.

Of the 3 nutrients considered, iron is the most complex in its interaction with the marine system. A certain concentration of iron is required for phytoplankton growth, and a higher concentration is required by diazotrophs. A major source of iron in the surface ocean is deposition of dust from the atmosphere. The global distribution of atmospheric dust is markedly non-uniform, as illustrated in Fig. 1.

$\begin{array}{ccccccccc}0.002 & 0.01 & 0.02 & 0.04 & 0.10 & \begin{array}{c}0.20 \\ \text { Fe }\left(\mathbf{g ~ m ~ m}^{-2} \mathbf{~ y r}^{-1}\right)\end{array} & & \end{array}$

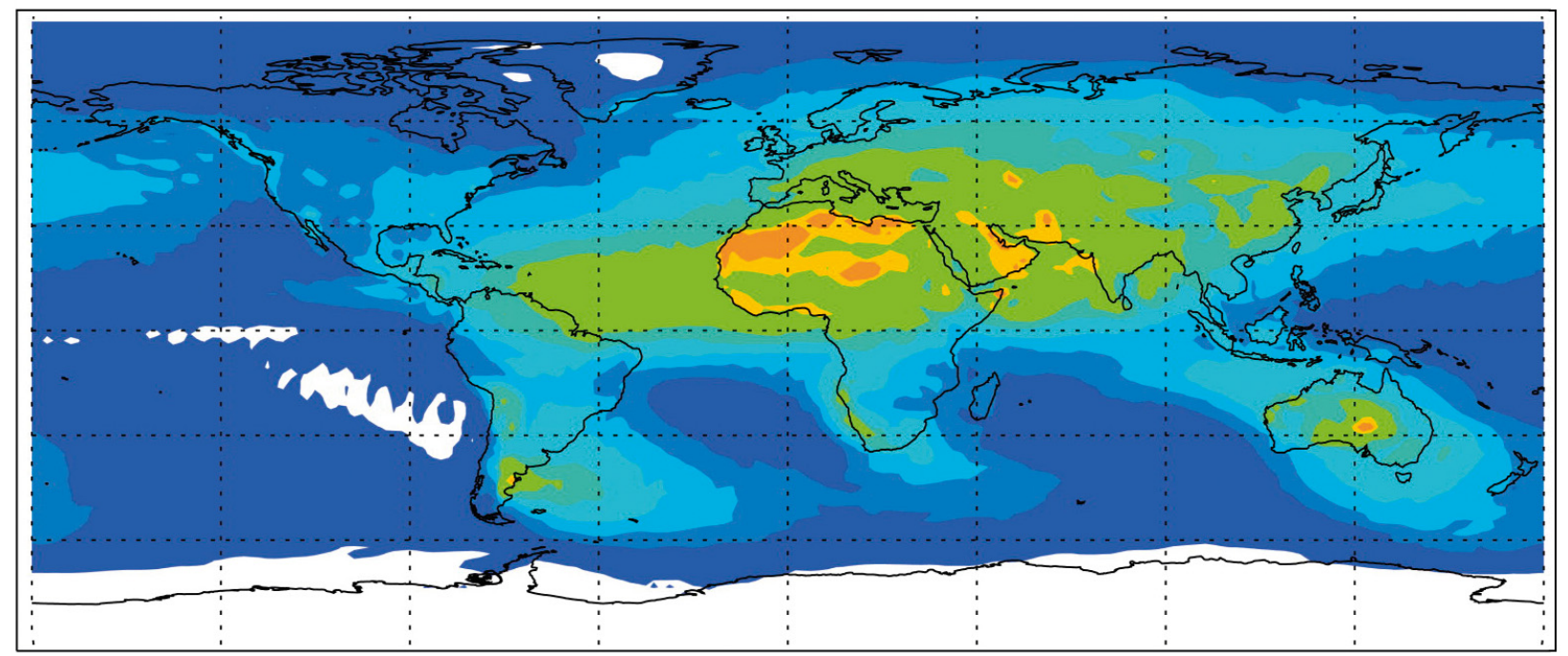

Fig. 1. Annual atmospheric deposition of iron $\left(\mathrm{g} \mathrm{Fe} \mathrm{m}^{-2} \mathrm{yr}^{-1}\right)$ after Mahowald et al. (2009) 
Some parts of the surface ocean have high concentrations of macronutrients but low chlorophyll concentrations (referred to as HNLC regions). This lack of chlorophyll productivity is believed to be substantially caused by a shortage of the micronutrient iron. Iron is not cycled in the same manner as other nutrients as it is very insoluble in the surface waters (with high concentrations of dissolved oxygen) and scavenged by falling particles. Iron attaches to falling detritus and is carried to the deep ocean. Phytoplankton needs iron because chlorophyll cannot be synthesised, or nitrate reduced, without a C:Fe ratio of 100 000:1 (Martin 1990, Martin et al. 1991). More recently, Klausmeier et al. (2008) placed the average composition of 15 phytoplankton species at a C:Fe ratio of 16 500:1. Martin (1990) points out that at his ratio, the ocean does not contain enough iron to support the conversion of all the nitrogen present. In those areas where all the nitrogen has been exported, enough iron must have been supplied during the lifetime of the water on the surface to allow all the nitrate to be consumed.

The processes controlling the loss of iron in deep water are not clear. Johnson et al. (1997) pointed out that the iron concentration at depth is not correlated with nitrogen concentrations, as one would expect from remineralisation of iron coming from the organic matter falling from the surface ocean. Rather, it seems rapid scavenging decreases the iron concentration to a low level which is maintained by iron binding ligands. Typically the upper ocean concentration of iron is low and rises to a value of about $0.6 \mathrm{nM}$ in all deep oceans. Scavenging appears to remove iron above a certain concentration. The concentration at a depth that might be upwelled is not much above the half saturation concentration of $0.12 \mathrm{nM}$ found in culture bottle experiments by Fitzwater et al. (1996).

In the case of nitrogen, the surface deposition is small, $54 \mathrm{Mt} \mathrm{N} \mathrm{yr}^{-1}$ according to Duce et al. (2008) compared with export of $1900 \mathrm{Gt} \mathrm{N} \mathrm{yr}^{-1}$. The implication is that, while nitrogen mostly travels with the carbon in continuous cycle, much of the iron is lost from the deep ocean and is not recycled. The notable differences in the recycling of the nutrients iron and nitrogen through the deep ocean are important in comparing intentional fertilisation of the surface waters.

Nitrogen suffers a second order effect as it cycles through the deep ocean. The organic nitrogen is 'denitrified' to the gases $\mathrm{N}_{2}$ or $\mathrm{N}_{2} \mathrm{O}$, which cannot be used by regular phytoplankton. Duce et al. (2008) placed the loss to $\mathrm{N}_{2} \mathrm{O}$ at about $5 \mathrm{Mt} \mathrm{Nyr}^{-1}$. The organic nitrogen lost by this process is mostly replaced by the action of cyanobacteria. In addition, some organic nitrogen is supplied to the ocean from the atmosphere and by river inflows.

Phosphorus, the other macronutrient considered, seems to be remineralised more rapidly than nitrogen since it is mostly found in the surface ocean at concentrations above the Redfield ratio (Tyrrell 1999). Usually it is assumed that nitrogen-fixing phytoplankton consumes phosphorus to keep the concentration of nitrogen and phosphorus close to the Redfield ratio for N:P in the long term.

Carbon dioxide is taken up by photosynthesis when light is available, while during dark periods it is respired. Net consumption of carbon dioxide, i.e. the difference between photosynthesis and respiration, is of focus for the present review.

Photosynthesis produces a number of by-products that can affect global temperatures. The photosynthetic process leads to the production of compounds that play a part in the formation of new atmospheric particles and hence cloud condensation. One such compound is methyl iodide $\left(\mathrm{CH}_{3} \mathrm{I}\right)$. This compound, when released from the sea surface, might lead to global cooling, via provision of cloud condensation nuclei, as discussed by Smythe-Wright et al. (2006). Another compound produced during photosynthesis is dimethyl sulphide (DMS), a gas of chemical composition $\left(\mathrm{CH}_{3}\right)_{2} \mathrm{~S}$. Oxidation of DMS in the atmosphere is involved in the formation of atmospheric sulphate particles, which can exert a climate cooling effect directly (by scattering and absorbing solar radiation) and indirectly by affecting cloudiness and hence global albedo (Turner et al. 1996).

\section{FERTILISATION}

Martin et al. (1990a) suggested iron fertilisation as a way to encourage new primary production in HNLC regions. At much the same time, Martin et al. (1990b) pointed out the possible climate implications of increasing local primary production. Subsequently there have been numerous in situ experiments in the Southern Ocean (e.g. Boyd et al. 2000), the equatorial Pacific (Martin et al. 1994, Coale et al.1996, 1998, Fitzwater et al. 1996, Gordon et al. 1998) and the high latitude Pacific (Tsuda 2003, Takeda \& Tsuda 2005). They all confirmed that enrichment of the surface HNLC water increased the conversion of inorganic carbon to organic matter locally.

For those regions deficient in macronutrients rather than iron, the addition of the limiting macronutrients has been suggested as a way to increase productivity (Jones 1996). Those regions of near-zero surface nitrogen are shown in Fig. 2. Three sources of increased macronutrient supply have been suggested: (1) reactive nitrogen fixed by cyanobacteria; (2) upwelled nutrients from the thermocline; and (3) ammoniabased products produced by the Haber-Bosch process that converts atmospheric $\mathrm{N}_{2}$ to reactive nitrogen. 


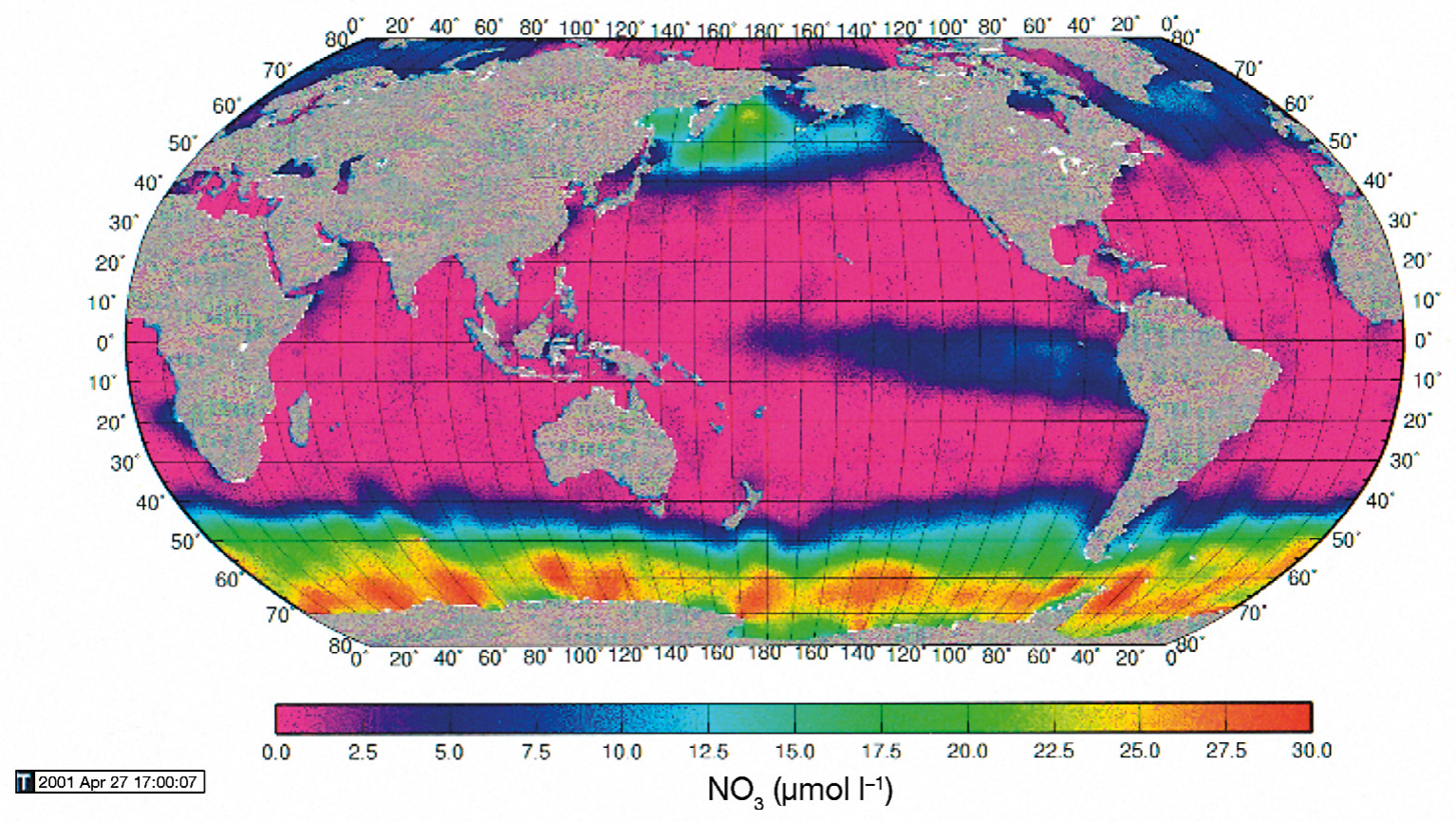

Fig. 2. Global map of nitrogen concentration in the surface ocean adapted from Levitus et al. (1994)

Yamasaki (2003) reviews sequestration options, which he sees as necessary in the short term.

\section{MICRONUTRIENT ENRICHMENT}

HNLC regions occur where there are low rates of atmospheric deposition of iron. The iron that is present in the photic zone is either upwelled, as discussed by Gordon et al. (1997) for the HNLC waters of the equatorial Pacific, or is supplied by atmospheric deposition. The many experiments in HNLC waters have been summarised by Boyd et al. (2007), while Gulf of Mexico experiments are described by Markels \& Barber (2001). In these experiments, soluble iron is added to the surface mixed layer. The phytoplankton nutrient limitation is relieved and photosynthesis is increased.

The concentration of added iron decreases at a faster rate than it is incorporated into organic matter (Fig. 3). The soluble iron within the enriched patch is scavenged by falling particles and transported out of the photic zone within about $10 \mathrm{~d}$. The increase of phytoplankton (Fig. 3b) is limited by zooplankton grazing as nitrate remains within the enriched patch. When the phytoplankton that remains from taking part in the new primary production dies, the chlorophyll concentration decreases as some dead phytoplankton is remineralised in the surface layer and some is exported from the surface layer. According to Boyd et al. (2004), dilution is a minor cause for decrease in concentration of particulate carbon in the enriched patch.
After remineralisation in HNLC surface water, iron is again limited. Hence, regenerated production does not generally occur locally. The deep exported carbon from the new primary production and its grazers are the only carbon stored in the deep ocean. The carbon remineralised in the seasonal thermocline is back in the surface ocean by the next winter and is not considered stored.

\section{MACRONUTRIENT ENRICHMENT}

\section{Reactive nitrogen fixed by cyanobacteria}

Land-based agriculture has long practiced in situ nourishment of the soil by growing plants, such as legumes, that fix nitrogen. An obvious analogy for the ocean is to arrange for the macronutrient nitrogen to be fixed by cyanobacteria. This was suggested by Markels \& Barber (2001), although they did not speculate on how this could be done. When there is adequate nitrogen, other phytoplankton prospers at the expense of cyanobacteria. In contrast, when inorganic nitrogen is in short supply, nitrogen fixers can be expected to have an ecological advantage. However, despite large expanses of oligotrophic ocean and adequate phosphorus supplies, there are limited amounts of nitrogen-fixing cyanobacteria in the ocean. The predominant cyanobacteria genera are Trichodesmium and Richelia, although the importance of smaller unicellular organisms is now being recognised (Zehr et al. 



Fig. 3. Iron fertilisation results reproduced from Boyd et al. (2004). (a) Iron concentration. : within the fertilized patch; $\mathbf{\square}$ : outside the patch. Iron was injected twice, on Day 0 and Day 6. (b) Phytoplankton growth, as measured by chlorophyll concentration within the enriched patch

2001). Breitbarth et al. (2006) noted that Trichodesmium does not fix $\mathrm{N}_{2}$ below $20^{\circ} \mathrm{C}$, as it is only found in the tropical and subtropical ocean (Capone et al. 1997). Small nitrogen-fixing bacteria extend this range somewhat. Falkowski (1997) cites Letelier \& Karl (1996) and others when stating that nitrogen fixation is limited by iron availability. There is evidence that cyanobacteria are more common in areas of the ocean with high dust input (and hence presumably with high iron concentrations).

As a result of field studies in the central Atlantic, Sañudo-Wilhelmy et al. (2001) reported that the nitrogen fixation rates appeared to be independent of the dissolved iron concentration in the surface ocean. Their calculations suggest that the concentration of iron required by cyanobacteria may be 2.5 to 5.2 times higher than by ammonium-assimilating phytoplankton. This would suggest that in iron-restricted situations with ample reactive nitrogen supplies, diatoms, rather than cyanobacteria, use the available iron (Schmidt \& Hutchins 1999).

Iron and phosphorus are not the only limiting nutrients. Paerl et al. (1987) found that concentrations of oxygen and DOM played a role in marine nitrogen fixation. The need for DOM was a clear result in their culture bottle experiments. Fu et al. (2005) concluded that dissolved organic phosphorus may be important in supporting cyanobacterial growth. Nitrogen-fixing bacteria when cultured by Needoba et al. (2007) showed neither iron nor phosphate were limiting their growth.

When cyanobacteria decay, the nitrogen originally fixed from the atmosphere by the cyanobacteria enters the pool of regenerated nutrients in the local surface ocean. Devassy et al. (1978) showed elevated concentrations of ammonia after a Trichodesmium bloom in the sea; a broad range of nutrients were also released as Trichodesmium decayed in culture bottles. Mulholland (2007) noted that cyanobacteria might not export carbon and nitrogen directly, as they tend to produce DOM which is taken up by bacteria. Some of the cyanobacteria are grazed by higher trophic levels and may then be exported as fecal pellets. However, since nitrogen levels are not rising, all of the fixed nitrogen is eventually exported either directly or through regenerated production or as a result of secondary production.

Cyanobacteria need the macronutrient phosphorus. Sañudo-Wilhelmy et al. (2001) produce some evidence that phosphorus limits nitrogen fixation in some regions of the ocean. Mahaffey et al. (2005) support this view. When Cullen et al. (2002) talk of continuous fertilisation with iron and phosphorus, are they thinking of encouraging cyanobacteria to fix more nitrogen? In the FeeP mesoscale experiments to examine these issues, Rees et al. (2007) found that in the north-east Atlantic, the 'microbial community was likely to be limited or co-limited by one or more nutrients in addition to $\mathrm{Fe}$ and $\mathrm{P}[\ldots]$ and nitrogen fixation [...] increased by up to 6 times and 4.5 times [...]' with addition of $\mathrm{Fe}$ and of $\mathrm{Fe}$ and $\mathrm{P}$, respectively.

There appear to be areas of local iron shortage where iron scavenging exceeds upwelling and atmospheric deposition. These areas could be targets for iron fertilisation for cyanobacteria conversion. There are boundless mineral deposits of iron that can simply dissolve in sea water by reacting with acid. Markels (2002) suggested that bound iron, which may survive scavenging due to organic complexation, might be more effective for iron fertilization. Providing soluble iron and phosphorus to the photic zone in low-nitrogen, iron-limited regions could be expected to allow an increase in production of organic nitrogen via enhanced cyanobacteria activity. The role of DOM in the fixation of nitrogen by bacteria as well as the iron biochemistry of the sea is unclear. The in situ fixing of nitrogen in the sea requires more mesoscale experiments to clarify the role of the various limitations. 


\section{Upwelled nutrients from the thermocline}

The waters near the top of the thermocline, but below the photic zone, are another source of macronutrients. Artificial upwelling of this thermocline water has been considered as a means of fertilising the photic zone.

One difficulty for those interested in carbon storage is that, while the thermocline is rich in nutrients remineralised in the deep ocean from organic matter, this organic matter also contained carbon. Such upwelled water, because of its age, may have left the surface ocean when the partial pressure of atmospheric carbon dioxide was lower. This component of the upwelled carbon may be undersaturated with carbon dioxide at present atmospheric conditions.

A Japanese research group (Toyota et al. 1991) raised up water in 1989 and 1990 from about 200 m depth. However, this did not produce a measurable increase in new primary production. The deep water probably diluted too quickly to cause a change in primary production measurable by the techniques used.

I estimated above (see 'Ocean carbon cycle') that it takes $220 \mathrm{~Sv}$ of upwelling to induce $17 \mathrm{Gt} \mathrm{C} \mathrm{yr}^{-1}$ of new primary production in the photic zone of the world's ocean. The nutrients in $10^{6} \mathrm{~m}^{3}$ (a Sverdrup second) of upwelled water will support the conversion of about $283 \mathrm{t}$ of inorganic $\mathrm{CO}_{2}$ to organic carbon. To raise water takes energy. Lovelock \& Rapley (2007) recently advocated using wave pumps to provide this energy. The Japanese group used electricity.

The artificial upwelling of the thermocline is not considered further in this discussion of carbon storage, because the high concentration of dissolved inorganic carbon in the upwelled water means that enhanced carbon storage via enhanced photosynthesis will be negligible.

\section{Haber-Bosch process}

Another way to provide the macronutrient nitrogen is by using the Haber-Bosch process to break the dinitrogen bond of atmospheric nitrogen. With a supply of energy, atmospheric nitrogen is combined with hydrogen supplied from steam or fossil fuels, and reacted over a catalyst to produce ammonia. The ammonia gas can be further reacted with carbon dioxide to produce urea. Agricultural activity uses much of this reactive nitrogen to enhance crop yields. Over-application of nitrogen fertiliser with its associated run-off has led to problems in rivers and estuaries.

Urea is readily taken up by phytoplankton (e.g. Eppley et al. 1973, Sambrotto \& Mace 2000), as are many other forms of inorganic nitrogen. Painter et al. (2008) deduced that urea provided 23 to $31 \%$ of the consumed nitrogen in any particular aquatic environment. In some locations, phosphorus can be a co-limiting nutrient (e.g. Thomas 1969, DiTullio et al. 1993). When nitrogen is the limiting nutrient, adding urea to the surface ocean will encourage phytoplankton growth and the conversion of inorganic carbon to organic biomass. While reports of iron and phosphorus fertilisation in mesoscale experiments exist, no such studies on nitrogen introduction have been published, but an experimental pilot plant design has been prepared by Jones \& Otaegui (1997). However, there are numerous culture bottle studies of nitrogen fertilisation of natural assemblages from oligotrophic waters (e.g. Menzel \& Ryther 1961, Tranter \& Newell 1968, Thomas 1969).

These culture bottle experiments all show that in low nitrogen regions, adequate micronutrients are present to support additional primary production. Fig. 4 shows a typical result, in which water from the Sulu Sea $\left(10^{\circ} \mathrm{N}, 122^{\circ} \mathrm{E}\right)$ was dosed with $8 \mu \mathrm{M}$ of nitrogen in the form of urea as well as sodium phosphorus in the Redfield ratio. In this example it appears that most of the added nitrogen was consumed by Day 5, and senescence set in.

New primary production will continue until it has exhausted all the added macronutrients (or if too much was added, after new primary production has exhausted some other critical nutrient). Remineralisation produces a set of regenerated nutrients able to again undergo primary production. It is assumed that there will be an adequate flux of iron from the atmosphere outside the HNLC ocean regions. This process of production of biomass, decay and remineralisation constitutes a cycling of the nutrients. This cycling in the surface ocean of the added nutrient continues until the added nutrient is fully exported to the deep ocean. The exported fraction of new primary production is of interest in iron fertilisation of HNLC regions (e.g. Trull et al. 2001). However, in the case of fertilisation by the limiting macronutrient, this new primary production export is not an issue, provided the ocean region has an adequate supply of iron. In this case, eventually all of the added nutrient is exported by a combination of new primary production followed by as many cycles of regenerative production as are required.

\section{Phosphorus}

In low-nitrogen, low-chlorophyll regions of the ocean, we need to consider the phosphorus concentration. In the northern hemisphere, phosphorus concen- 


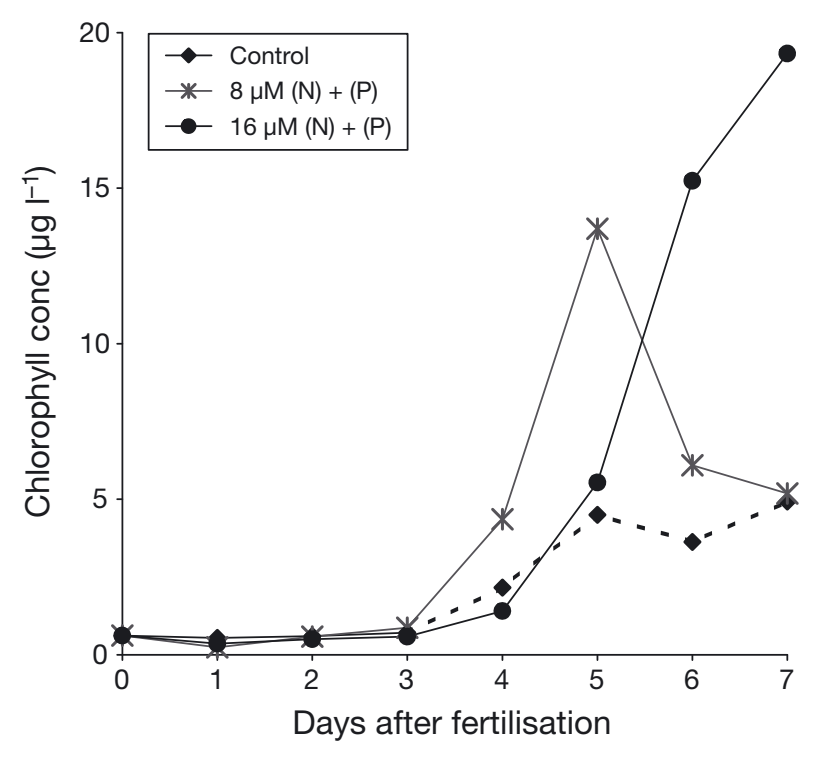

Fig. 4. Culture bottle results of fertilising water from the Sulu Sea. Control and enrichment with $\mathrm{N}+\mathrm{P}$ are shown. A dosage of $8 \mu \mathrm{M}$ of nitrogen on Day 1 led to a maximum concentration of chlorophyll on Day 5, while the bottle with larger dosage had yet to peak on Day 7. Biomass was mostly diatoms. Modified from Harrison (2007)

tration, like that of nitrogen, is very low in surface ocean waters warmer than about $20^{\circ} \mathrm{C}$ (e.g. Sarmiento \& Gruber 2006). This suggests cyanobacteria such as Trichodesmium have consumed the phosphorus and provided reactive nitrogen to the upper ocean. However in most of the rest of the low-nitrogen ocean, phosphorus concentrations are high enough to support additional photosynthesis if reactive nitrogen was supplied by either the Haber-Bosch process or by cyanobacteria.

Iron concentration plays a part in determining the viability of fertilising with phosphorus for various regions of the ocean. Various situations of relevance follow:

(1) The iron concentration is too low for (ammoniaconsuming) phytoplankton to multiply. Since we are considering regions of low nitrogen, there must have been adequate concentrations of iron in the past. Large regions with these characteristics are unlikely.

(2) The iron concentration is too low for diazotrophs but sufficient for ammonia-consuming phytoplankton to multiply; however, there is too little nitrogen. The addition of iron may enhance diazotroph production in this case.

(3) There is adequate iron for diazotrophs but some element other than phosphorus is missing. Paerl et al. (1987) reported a situation where neither iron nor phosphorus addition (separately) enhanced nitrogen fixation. This is a difficult situation and not a region one would choose to fertilise with our present level of knowledge.

In addition to these 3 cases, the polar regions have adequate nitrogen and phosphorus levels, but the iron concentrations are below those needed by both ammonia-consuming phytoplankton and diazotrophs.

In regions where the phosphorus concentration is very low, it will be necessary to add phosphorus obtained by mining phosphate rock if additional photosynthesis is desired. Thus nourishment can proceed by adding Haber-Bosch nitrogen with the phosphate (in situations with adequate iron) or by adding phosphate and iron to support diazotroph production of reactive nitrogen and regenerative production. The former option may be chosen if there is concern about the iron concentrations needed by diazotrophs. Lenton \& Vaughan (2009) considered the capacity of either nitrogen or phosphorus to store carbon, but a much greater sequestration could be obtained by the combination of nitrogen and phosphorus. If one also relaxes the assumption that phosphorus is only supplied at the rate of agricultural demand, the storage of carbon in 2050 suggested by Lenton \& Vaughan (2009) could be greatly exceeded.

The process of phosphate and iron fertilisation in an example of natural ocean nourishment was observed by Subramaniam et al. (2008). The Amazon River plume transports phosphorus and iron into the Atlantic Ocean, which supports the growth of diazotrophs which fix about $3 \mathrm{Mt} \mathrm{N} \mathrm{yr}^{-1}$.

In regions with negligible phosphorus concentration, the addition of phosphorus obtained by mining may support diazotrophs and subsequently regenerative production. It is not clear how many of these regions would also need a higher concentration of iron. Adding iron to the phosphate is not difficult and would probably be a prudent action.

\section{ADVECTION OF FERTILISED WATER}

The addition of iron to HNLC regions can effectively steal other nutrients. Aumont \& Bopp (2006) found in their model studies that nutrient stealing reduced the global additional primary production by $50 \%$ of what it would have been. In the unfertilised HNLC ocean, iron limits photosynthesis, and the excess macronutrients are exported by 'Ekman flow' to the subtropical gyres. When the macronutrients are consumed (because of fertilisation) before the surface waters arrive in these regions of adequate iron input, the waters are now macronutrient-limited. As a consequence, iron nourishment of HNLC waters is unlikely to be a major contributor to managing climate change. 
Dutkiewicz et al. (2005) show in their model that if the dust supply to the world's oceans were increased (effectively iron fertilisation), then large regions of the temperate oceans would experience a decrease in primary production because of macronutrient limitations. The extra primary production (resulting from the dust) in HNLC regions would export nutrients from the surface ocean. These nutrients, following advection, might have otherwise been used in the temperate oceans. The global response of the model to additional dust is an increase of only a few percent in primary production (and hence presumably also in export production).

Gnanadesikan et al. (2003) found much the same reduction of primary production when they modelled patch fertilisation of the equatorial Pacific. As the ironfertilised patch drifted across the Pacific, it supported less primary production than a non-fertilised patch. The surface ocean has a refreshment time of a decade, allowing ample time for atmospheric deposition of iron to eventually cause all the nitrogen to be exported from the unfertilised waters of the temperate oceans.

Given that iron fertilisation leads to macronutrient stealing, it is interesting to consider whether there is a similar effect for macronutrient fertilisation. The addition of macronutrients will consume trace nutrients. Might macronutrient enrichment of low nitrogen regions of the surface ocean be another form of nutrient stealing? Could nourishment of one region cause deficits in trace nutrients in some currently productive areas? At present, there are no areas of the ocean recognised as having limiting trace nutrients (except iron). Bottle studies of enrichment with macronutrients could determine if there are regions of the ocean that lack enough trace elements to support further phytoplankton growth.

If only nitrogen were to be added in regions with residual phosphorus, the export of the phosphorus in the organic matter could limit diazotrophs later in the lifetime of the surface water. Gruber (2008) estimated that diazotrophs fix 100/5.7 = 17.5 $\mathrm{Mt} \mathrm{N} \mathrm{yr}^{-1}$ and so using the Redfield ratio, consume 100/41 $=2.4$ Mt P $\mathrm{yr}^{-1}$. The excess $\mathrm{P}$ supplied to the surface ocean (discussed in 'Strategies for ocean fertilisation') is 155/7.2 $=21.5 \mathrm{Mt} \mathrm{P} \mathrm{yr}^{-1}$. Thus the least uncertain approach to fertilisation would be to add the complete spectrum of nutrients. Artificial upwelling would accomplish such fertilisation, but is unfortunately not a promising enough method for providing nutrients to manage atmospheric carbon dioxide concentrations.

Advection of those nutrients remineralised in the surface waters means that regenerative production takes place in a different geographical location from the new primary production. Thus, for macronutrient fertilisation, export to deep waters occurs over a much larger area than the patch initially fertilised, and this means that looking for exported carbon with sediment traps is not likely to capture even a representative sample of the exported carbon.

\section{REMINERALISATION AFTER EXPORT}

The depth at which the organic material is remineralised depends on the species that prosper from enrichment of the surface water. However, all 3 choices of providing nitrogen are likely to produce much the same distribution. All 3 fertilisation approaches rely on regenerated production to export most of the carbon. In contrast, HNLC regions with micronutrient fertilisation have to rely predominantly on new primary production. Different forms of nitrogen may lead to different species composition in the new primary production and different export depths. For example, diatoms with their silica framework are expected to be remineralised at greater depths than small bacteria. We speculate that the initial form of the nitrogen will have little impact on the export depth of regenerative production.

As well as exporting carbon from the surface ocean, some phytoplankton exports calcium carbonate. An example is coccolithophorids, which have an armour of small $\mathrm{CaCO}_{3}$ plates. The loss of calcium carbonate causes the $\mathrm{CO}_{2}$ partial pressure of the surface water to rise, which is the opposite effect to what one might expect intuitively. The net effect of the export of coccolithophorids is a smaller net reduction of partial pressure per unit of added nitrogen than for the export of diatoms. Particulate inorganic carbon (PIC) exported from the surface ocean has been estimated by Berelson et al. (2007) to be in excess of 1.6 Gt $\mathrm{C} \mathrm{yr}^{-1}$, but this quantity will decrease in the future because of ocean acidification. Matear \& Elliott (2004), in their modelling studies, thought that inorganic carbon production as a result of enrichment might reduce the effectiveness of sequestration of carbon by up to $25 \%$. This fraction probably depends on the concentration of silica, which influences the number of diatoms present to compete for nitrogen. If the species composition is much the same in the regenerated production (where most of the export takes place) as in the new primary production, the impact of PIC will be much the same for any enrichment and will not be considered further.

The marine snow is remineralised in approximately the Redfield ratio of elements, C:N:P, 106:16:1. Most of the constituents of the organic matter (with the notable exception of iron) return to the surface waters after hundreds to thousands of years (see below). On return of the deep exported matter (now in inorganic form in the Redfield ratio) to the photic zone, the sunlightaided conversion to organic matter leads to no loss of 
stored carbon dioxide back to the atmosphere, provided there is an adequate supply of atmospheric iron.

However, some of the exported nitrogen can suffer denitrification in the lower oxygen reaches of the deep ocean and might not return to the photic zone in a suitable form for phytoplankton uptake. This reduces the reactive nitrogen in upwelled water and leads to a loss of the previously stored carbon. If the nitrogen is converted to $\mathrm{N}_{2} \mathrm{O}$ in the deep ocean, this powerful greenhouse gas reduces the climate benefits of the initial storage of carbon. In the case of iron nourishment this was assessed by Jin \& Gruber (2003) as quite substantial. The ventilation of the ocean refreshes the oxygen which is consumed in the remineralisation of marine snow, limiting the amount of $\mathrm{N}_{2} \mathrm{O}$ produced. A little of the marine snow settles on the ocean floor. Here the carbon is permanently sequestered, but the nitrogen is remineralised and denitrified on the sea floor. This provides additional nitrogen to be upwelled, some of it available to again sequester carbon. Ocean-wide nitrification is on the order of $100 \mathrm{Mt} \mathrm{N} \mathrm{yr}^{-1}$ according to Gruber (2008), but there is considerable uncertainty. This is about a $5 \%$ loss of $\mathrm{N}$ each time decomposed marine snow is upwelled into the photic zone. This lowers the N:P ratio of upwelled waters and allows an opportunity for cyanobacteria to flourish.

An important difference between relieving iron limitation of macronutrient-rich waters and relieving macronutrient limitation is that iron is scavenged from the surface ocean and the thermocline by sinking particles. Parekh et al. $(2004,2005)$ were unable to resolve whether the iron was lost, desorbed or complexed with organic ligands after it was scavenged. Dissolved iron concentration does not increase with the dissolved oxygen deficiency of the deep water as one would expect from remineralisation of sinking organic matter. However, Bergquist \& Boyle (2006) pointed out that, to make a quantitative statement about the fate of the iron, one needs to know an equivalent effective scavenging rate.

The geographical location of the iron-limited water that is fertilised determines how quickly the exported carbon is recycled to the surface ocean, and how much of the introduced iron remains when the water again reaches the photic zone.

Macronutrient nourishment can be carried to regions where iron is not the limiting nutrient. Here, the residence time of exported carbon is different, as most of the added nutrient is not lost but is instead available to be used again after upwelling. The scavenging of iron (or at least the uncertainty about scavenged iron) makes iron fertilisation of HNLC waters a less promising option for long-term storage of carbon than macronutrient nourishment. Denitrification plays an equivalent role to iron scavenging, by limiting carbon storage time due to nitrogen addition to the ocean.
The time for water to return to the surface depends on its depth and the location. The time for surface water to reach a location is termed the age (Matsumoto 2007). Very loosely, the age of water at a depth of $1500 \mathrm{~m}$ is less than $300 \mathrm{yr}$ in the Atlantic south of $40^{\circ}$ latitude, less than $800 \mathrm{yr}$ south of the equator and less than 1200 yr elsewhere. Age, however, is not the time for the water to return to the surface. Modelling by Orr \& Aumont (1999) showed that for remineralisation at a depth of $1500 \mathrm{~m}$ (in their case injection of a tracer) it took $200 \mathrm{yr}$ for half the tracer material to reach the surface at some locations and more than $500 \mathrm{yr}$ at others.

The 'short' residence time of exported carbon in the Southern Ocean before the carbon returns to the surface ocean partly explains the low efficiency for iron fertilisation in the Southern Ocean. For example, Aumont \& Bopp (2006) found that $75 \%$ of the carbon exported was upwelled and returned to the surface ocean in the first $100 \mathrm{yr}$ of iron fertilisation. On return of the exported matter, carbon escapes to the atmosphere, because the upwelled nutrients lack iron. The cycle of macronutrients and iron is decoupled (Parekh et al. 2005). Other researchers (e.g. Zeebe \& Archer 2005) found greater carbon 'leakage'.

\section{SPECIES RESPONSE}

\section{Trophic level 1}

In the upper ocean, bacteria and phytoplankton compete for nutrients. Free bacteria utilise DOM released by phytoplankton. Larger organisms tend to consume smaller organisms. The picozooplankton consumes smaller bacteria and are in turn consumed by microplankton (2 to $10 \mu \mathrm{m}$ ). Azam et al. (1983) suggested that this step provides a connection between the bacterial cycle and the phytoplankton cycle. Barren areas of the ocean are dominated by bacteria of small size $(<2 \mu \mathrm{m})$ with nutrients cycling between phytoplankton, bacteria and zooplankton. Cullen et al. (2002) suggested that picoplanktonic organisms dominate phytoplankton in oligotrophic waters, where their small size gives them an advantage in obtaining the limited nutrients available. The concentration of bacteria is limited by grazing by picozooplankton $(<2 \mu \mathrm{m})$. The small export ratio of the picoplankton biomass, discussed by Michaels \& Silver (1988), results in nutrients being reused many times before being exported to the deep ocean. Some of the nutrients in the microzooplankton move up the size chain, while some is converted to DOM to be used by bacteria.

Upon enrichment with iron in HNLC regions, the larger phytoplanktonic organisms are relieved of their iron limitation and can now access the available nitrate 
and phosphorus. If there is adequate silica present, the phytoplankton assemblage includes diatoms. Indeed, iron enrichment experiments report increases in the diatom populations. Diatoms store nutrients at a more rapid rate than the picophytoplankton, and they can adjust their buoyancy to find nutrients (Sarmiento \& Gruber 2006, p. 279). Because of their size, diatoms are relatively efficient exporters of carbon.

The situation is different in the case of macronutrient enrichment. The species which responds most rapidly to macronutrient addition depends on the nutrients provided. When the nutrients encourage cyanobacteria, the diazotrophs provide DOM, which is used by picoplankton with subsequent regenerated production. One assumes that on the second reuse of the nutrients (regenerative production) it matters little what form of nitrogen was supplied for additional new production. In the absence of silica, dinoflagellates are expected to be more prominent. Harrison's (2007) measurements found that Haber-Bosch urea supported diatom growth, suggesting that there was residual silica at the site investigated.

The larger phytoplankton sinks faster upon senescence, but the community composition is of secondary importance in the case of macronutrient nourishment. Those introduced macronutrients that are not exported during new primary production are available for further photosynthesis in the future. As many have pointed out, the regenerated production leads to the export equalling the new primary production (e.g. Eppley \& Peterson 1979, Najjar et al. 2007, Yool et al. 2007). Carbon and nutrients are exported from the surface layer, either as particles or subducted as DOM. If all the new production (that is the first pass through the food web) was not exported, there would be a build-up of nutrients (e.g. nitrogen) in the upper ocean. This is not observed, and there are no significant losses of macronutrients, for example through the sea surface. However, the above considerations apply to spatial averages as pointed out by Plattner et al. (2005). The regenerated production may be many kilometres away from the site of the original new production, as the currents carry the surface waters containing the partially reformed matter many hundreds of kilometres.

In the presence of adequate macronutrients, excess iron favoured the growth of larger phytoplankton in the culture bottle experiments of DiTullio et al. (1993). They did not observe greatly enhanced production but a change in species distribution. Their results suggest that iron fertilisation of HNLC regions might lead to deeper export of carbon than enhancing the macronutrients in oligotrophic regions. A small percentage of the exported organic matter reaches the sea floor, and again, iron fertilisation might deposit more carbon in the deep water sediments.
The production of more harmful algal blooms (HAB) could be an undesirable outcome of enrichment if enhanced toxicity caused ecologically unwanted impacts. A number of iron enrichment experiments produced Pseudo-nitzschia spp. which have the capacity to produce the potent neurotoxin domoic acid. Allsopp et al. (2007) pointed out that there was no evidence of harmful algae during the mesoscale experiments. However, Trick et al. (2010) created neurotoxin by adding iron to culture bottles containing Pseudonitzschia spp. and found that the specific composition of commercial iron substrates is a critical parameter in the degree of toxin production. Would the same result be found in iron-rich areas where algae growth was triggered by the addition of macronutrients? The answer to this question is not clear at this time.

Zettler et al. (1996) found that iron benefitted only large diatoms in a series of bottle experiments in the equatorial Pacific. Diatoms also favour ammonia over nitrate (Eppley \& Renger 1974). Cullen et al. (2002) suggest that red tide producing dinoflagellates prosper in high-nutrient, low-turbulence situations. High concentrations of silica allow diatoms to outcompete dinoflagellates. By restricting the concentration of nutrients provided during enrichment, one can avoid high nutrient situations and possibly lower the risk of HAB.

With more chlorophyll, increased production of DMS is expected. The choice of fertilisation would impact on DMS production only through species differences.

\section{Trophic level 2}

Zooplankton provides another path for the export of carbon to the deep ocean. Its faecal pellets contribute to the export of both carbon and nutrients from the surface ocean. Zooplankton has a relatively slow growth rate compared with phytoplankton. Thus, the concentration of phytoplankton in a patch of enriched water can initially increase without an immediately significant increase in grazing pressure. To estimate the new primary production caused by enrichment, the portion grazed by zooplankton and vegetarian fish must be included. The iron mesoscale experiments reported by Zeldis (2001) did not show much zooplankton increase inside the enriched patch. The patch showed an 8-fold increase of primary production $13 \mathrm{~d}$ after iron fertilisation, but less than $1 \%$ was consumed by zooplankton according to Zeldis (2001). In a longer experiment (26 d), Tsuda et al. (2007) found mesozooplankton mass was 3 to 5 times higher in the patch, and mesozooplankton grazing had a marked impact on the phytoplankton concentration.

In the CYCLOPS experiment, where phosphoric acid was added to the surface water, copepod egg abun- 
dance increased over the first few days (Thingstad et al. 2005). This response occurred as the concentration of chlorophyll decreased, and Thingstad et al. (2005) speculated that the extra phosphorus available in heterotrophic bacteria is the signal for egg production.

It is believed that the microbial community does not contribute much to the supply of food for the higher trophic levels (Azam et al. 1983). Efficient grazing by zooplankton is required if energy captured by primary production is to flow to higher trophic levels. Rapid egg production is needed. In order to achieve a pulse of phytoplankton that lasts long enough for transfer to the next trophic level, the distribution of nutrients must be sufficiently concentrated. Nutrient infusion techniques able to produce the required level of nutrient after a number of days of diffusion are discussed by Markels (2002) and Judd et al. (2009).

\section{STRATEGIES FOR OCEAN FERTILISATION}

In situations where iron, phosphorus or nitrogen limit new primary production, a number of strategies for ocean fertilisation are available depending on the location and the season. These are:

(1) Iron fertilisation in HNLC waters.

(2) Iron fertilisation in LNLC (low-nitrogen, lowchlorophyll) waters with residual phosphorus.

(3) Iron and phosphorus fertilisation in LNLC waters.

(4) Nitrogen fertilisation in LNLC waters with residual phosphorus.

(5) Nitrogen and phosphorus fertilisation in LNLC waters.

The first 2 strategies can be considered micronutrient fertilisation, while the latter 3 are macronutrient nourishment. In those cases where there is sufficient phosphorus but insufficient nitrogen (Strategies 2 and 4 ), it is assumed that the iron concentration is adequate for phytoplankton to use any available nitrogen but inadequate for cyanobacteria to use the phosphorus.

The nutrients can be added over time either at a particular geographic location or to the same patch of water by following it as it is advected. The first approach (in which ocean currents bring unfertilised water each day) can be considered similar to a number of independent mesoscale patch experiments of the type that have been performed to date. The plume of new nutrients will with time become a plume of regenerated nutrients, becoming more dilute with time due to diffusion and export.

Buesseler \& Boyd (2003) addressed their question 'Will ocean fertilisation work?' by considering observations made during mesoscale iron enrichment experiments in the Southern Ocean and did not consider fertilisation by macronutrient addition or by artificially induced cyanobacteria production of nitrogen. They


amount corresponds to the observed annual increase in atmospheric carbon, and to store all this using one approach is very ambitious. They concludeed that this goal cannot be met by 1 injection of iron per year with characteristics of the SOIREE experiment described by Boyd et al. (2000). The iron injection in SOIREE exported about $2000 \mathrm{t}$ of carbon and, assuming the Redfield ratio, about $300 \mathrm{t}$ of nitrogen were exported. Such a small export of nitrogen had no impact on the nitrate concentrations in a $1000 \mathrm{~km}^{2}$ patch of fertilised water. If Boyd et al. (2000) had considered a number of iron injections during the summer instead of just 4 injections over $8 d$, the quantity of carbon exported would have been higher, and the limitation on primary production by predominantly diatoms might have been available silicon instead of available nitrogen.

While Buesseler \& Boyd (2003) and others discuss the export fraction of new primary production, this is an issue only in HNLC areas such as the Southern Ocean, where regenerated production is limited. As pointed out above ('Advection of fertilised water'), however, the stealing of nutrients is an important issue for HNLC regions that casts doubt on the effectiveness of iron fertilisation as either a sink of carbon or as a method to increase the global new primary production.

When does nourishment using Haber-Bosch nitrogen need to include phosphorus? Anderson \& Sarmiento (1994) found that the N:P ratio is always less than 16 in the deep ocean. They speculated that $\mathrm{P}$ is remineralised more rapidly than $\mathrm{N}$. Organic $\mathrm{P}$ is converted to its inorganic form at a shallower depth than $\mathrm{N}$ and so returns more quickly to the photic zone. Some nitrogen also escapes the ocean as dinitrogen or nitrous oxide. This leads to a Redfield ratio of N:P of less than 16, and Falkowski (1997) suggested that the dissolved inorganic phosphorus in the ocean needs on average $2.7 \mu \mathrm{M}$ of additional nitrogen to be in the Redfield ratio. Some of this 'missing' nitrogen may be provided in the photic zone by nitrogen-fixing bacteria, but let us assume the nitrogen is all supplied by macronutrient addition. A global upwelling estimate of $129 \mathrm{~Sv}\left(4.1 \times 10^{15} \mathrm{~m}^{3} \mathrm{yr}^{-1}\right)$ is equivalent to $13 \mathrm{~m} \mathrm{yr}^{-1}$. The nitrogen 'deficit' flux is $2.7 \times 14 \times 10^{-3} \times 4.1 \times 10^{15} \mathrm{~g}$ $\mathrm{N} \mathrm{yr}^{-1}=155 \times 10^{6} \mathrm{t} \mathrm{N} \mathrm{yr}^{-1}=155 \mathrm{Mt} \mathrm{N} \mathrm{yr}^{-1}$. As we would expect, the deficit flux is considerably smaller (5\%) than the estimate made earlier of the export flux being 3 Gt $\mathrm{N} \mathrm{yr}^{-1}$. Lenton \& Vaughan (2009) suggest that the deficit is a higher percentage of nitrogen flux. In general, the nitrogen in the organic carbon cycle is circulating at between $1550 \mathrm{Mt} \mathrm{N} \mathrm{yr}^{-1}$ according to Gruber (2008) and $3000 \mathrm{Mt} \mathrm{N} \mathrm{yr}^{-1}$. Such fluxes of nitrogen are consistent with the earlier discussion of new primary production or export production. The flux of unused 
phosphate (concentration $2.7 \div 16 \mu \mathrm{M}$ ) can be estimated to be $4.1 \times 10^{15} \times(2.7 \div 16) \times 10^{-3}=0.7 \times 10^{12} \mathrm{~mol}$ $\mathrm{yr}^{-1}$. If nitrogen were added to combine with the supply of unused phosphorus, then $106 \times 0.7 \times 10^{12} \mathrm{~mol} \mathrm{C}$ $\mathrm{yr}^{-1}=74 \times 44 \mathrm{Mt} \mathrm{CO}_{2} \mathrm{yr}^{-1}=3256 \mathrm{Mt} \mathrm{CO}_{2} \mathrm{yr}^{-1}$ would enter the organic carbon cycle. This result is approximately the same as that estimated by Marinov et al. (2008). After some length of time, with addition of new nitrogen only, all the excess phosphorus in the deep ocean in excess of the Redfield ratio would have been fully utilised. Matear \& Elliott (2004) suggest that current surface phosphorus would support greater than $0.8 \mathrm{Gt} \mathrm{C}$ of carbon export.

The discussion of the constraints of large-scale increases in ocean productivity does not mean that such an increase will likely occur at once. Just as the changes to the terrestrial ecology have been implemented gradually (doubling grain productivity took half a century), Jones (2001) looked at the deployment of 300 Haber-Bosch nitrogen manufacturing factories (each of $0.6 \mathrm{Mt} \mathrm{N} \mathrm{yr}^{-1}$ capacity) over $50 \mathrm{yr}$. Unless phytoplankton with low phosphorus demand prospered, such a scenario would more than use up the residual phosphorus currently unused in the surface ocean.

The estimation of the amount of carbon stored by deep export as a result of fertilisation is worthy of discussion. While the amount of new primary production can be estimated from surveys of the enriched plume or patch, the fraction that is finally exported is more difficult to measure directly. In the case of iron fertilisation, the scavenging of the iron suggests that there will be little regenerative production in the surface ocean. Export will be limited to some fraction of the new primary production. In the case of nourishment with nitrogen alone or nitrogen and phosphorus together, regenerative production will, over time, export all the new primary production. However, the export will be spread out over hundreds of kilometres as the surface water is advected around the ocean gyres.

\section{CONCLUSION}

Since Martin et al. (1990a,b) suggested using the regions of the surface ocean that contain unutilised macronutrients to manage the climate, the concept has been further extended to embrace the purposeful introduction of the limiting nutrient to store carbon while at the same time increasing the production of marine protein. To understand the impact of ocean enrichment it needs to be recognised that the surface water of the ocean, during its decade-long stay at the surface, is transported large distances by the current systems that occupy each ocean basin. During this period, new water rich in nutrients enters the surface ocean. There is some input of nutrients from the rivers and the atmosphere as well as entrainment of nutrientrich water from the top of the permanent thermocline. In particular the concentration of iron and nitrogen will change during the surface water's decade-long life time.

While the intentional macronutrient nourishment and micronutrient fertilisation with iron have many similarities, there are significant differences between the 2 strategies, in terms of nutrient losses, regenerative primary production, nutrient stealing, techniques for measuring storage and the cost of production of organic matter. In addition, the possible, unintended consequences could differ.

Iron is rapidly scavenged from the ocean and replenished only slowly by upwelling, diffusion or atmospheric deposition. Creating new primary production by the addition of iron in nitrogen-rich water is not expected to lead to regenerative production in the photic zone due to the loss of the added micronutrient in the surface waters. In situations with adequate supply of iron, additional nitrogen could be supplied by any of 3 methods. All these methods are expected to support both new primary production and regenerative production until all the additional nitrogen is exported from the surface ocean or until another nutrient becomes limiting.

Critics of ocean fertilisation have often focused on the rapid return of the carbon exported by iron fertilisation of the Southern Ocean HNLC region. Since it is assumed that most of the iron exported with the organic matter is lost in the deep ocean, some of the carbon, nitrogen, etc. joins the HNLC region upon return to the surface, and the earlier addition of iron ceases to retain the previously exported carbon in the ocean.

Macronutrient stealing is a multipart processs. First, nitrogen is exported from the surface ocean as a result of supplying iron to one location. Next, the nitrogen depleted surface water drifts to a new location which has an adequate natural iron supply. This results in diminished biological production at the new location. With macronutrient nourishment, additional micronutrients are consumed and exported. Might they be needed for primary production as the water drifts to regions of atmospheric nitrogen deposition or diazotroph activity? Where nitrogen or phosphorus limit phytoplankton growth, culture bottle studies of natural assemblages show that in most regions, the water contains adequate micronutrients to respond to modest macronutrient nourishment. Clarification of the possibility of significant micronutrient stealing awaits further study. However, the lack of reports of micronutrient limitation, with the exception of iron, suggests that 
such a limitation may only become an issue for aggressive macronutrient nourishment.

Supplying the limiting macronutrient nitrogen seems the most promising approach at this time. Using this strategy, most of the export of carbon will not be in the new primary production cycle but will come from regenerated production or from grazing by higher trophic levels. On its return from the deep ocean, the added nitrogen again participates in photosynthesis in regions where there is adequate iron, and it continues to store the previously sequestered carbon. Further mesoscale experiments are required to determine whether nitrogen nourishment can be carried out with the help of cyanobacteria or whether the certainty of the HaberBosch supplied nutrient (together with phosphorus in some places) is the most effective technological method of increasing global ocean productivity.

Acknowledgements. I thank M. W. Lawrence for his interest in my activities over the years and his comments on this paper.

\section{LITERATURE CITED}

Allsopp M, Santillo D, Johnston P (2007) A scientific critique of oceanic iron fertilization as a climate change mitigation strategy. Greenpeace Research Laboratories, Technical Note 07/2007, available at www.greenpeace.to/publications/ iron_fertilisation_critique.pdf

Anderson LA, Sarmiento JL (1994) Redfield ratios of remineralization determined by nutrient data analysis. Global Biogeochem Cycles 8:65-80

Aumont O, Bopp L (2006) Globalizing results from ocean in situ iron fertilization studies. Global Biogeochem Cycles 20:GB2017, doi:10.1029/2005GB002591

Azam F, Fenchel T, Field JG, Gray JS, Meyer-Reil LA, Thingstad F (1983) The ecological role of water column microbes in the sea. Mar Ecol Prog Ser 10:257-263

Berelson WM, Balch WM, Najjar R, Feely RA, Sabine C, Lee $\mathrm{K}$ (2007) Relating estimates of $\mathrm{CaCO}_{3}$ production, export, and dissolution in the water column to measurements of $\mathrm{CaCO}_{3}$ rain into sediment traps and dissolution on the sea floor: a revised global carbonate budget. Global Biogeochem Cycles 21:GB1024, doi:10.1029/2006GB002803

Bergquist BA, Boyle EA (2006) Dissolved iron in the tropical and subtropical Atlantic Ocean. Global Biogeochem Cycles 20:GB1015, doi:10.1029/2005GB002505

Bienfang PK, Ziemann DA (1992) The role of coastal high latitude ecosystems in global export production. In: Falkowski PG, Woodhead AD (eds) Primary productivity and biogeochemical cycles in the sea. Plenum Press, New York, NY, p 285-298

Boyd PW (2008) Implications of large-scale iron fertilization of the oceans. Mar Ecol Prog Ser 364:213-218

Boyd PW, Watson AJ, Law CS, Abraham E and others (2000) A mesoscale phytoplankton bloom in the polar Southern Ocean stimulated by iron fertilization. Nature 407: 695-702

Boyd PW, Law CS, Wong CS, Nojiri Y and others (2004) The decline and fate of an iron-induced subarctic phytoplankton bloom. Nature 428:549-553
Boyd PW, Jickells T, Law CS, Blain S and others (2007) Mesoscale iron enrichment experiments 1993-2005: synthesis and future direction. Science 315:612-617

Breitbarth E, Oschlies A, LaRoche J (2007) Physiological constraints on the global distribution of Trichodesmiumeffect of temperature on diazotrophy. Biogeosciences 4 : 53-61

Broecker WS, Peng TH (1982) Tracers in the sea. LamontDoherty Geological Observatory, Palisades, NY

Buesseler KO, Boyd PW (2003) Will ocean fertilization work? Science 300:67-68

Capone DG, Zehr JP, Paerl HW, Bergman B, Carpenter EJ (1997) Trichodesmium, a globally significant marine cyanobacterium. Science 276:1221-1229

Coale KH, Johnson KS, Fitzwater SE, Gordon RM and others (1996) A massive phytoplankton bloom induced by an ecosystem-scale iron fertilization experiment in the equatorial Pacific Ocean. Nature 383:495-501

Coale KH, Johnson KS, Fitzwater SE, Blain SPG, Stanton TP, Coley TL (1998) IronEx-I, an in situ iron-enrichment experiment: experimental design, implementation and results. Deep-Sea Res II 45:919-945

Cullen JJ, Franks PJS, Karl DM, Longhurst A (2002) Physical influences on marine ecosystem dynamics. In: Robinson AR, McCarthy JJ, Rothschild BJ (eds) The sea, Vol 12. John Wiley \& Sons, New York, NY, p 297-336

de Baar HJW, Boyd PW, Coale KH, Landry MR and others (2005) Synthesis of iron fertilization experiments: from the iron age in the age of enlightenment. J Geophys Res 110:C09S16, doi:10.1029/2004JC002378

> de Boyer Montegut C, Madec G, Fischer AS, Lazar A, Iudicone D (2004) Mixed layer depth over the global ocean: an examination of profile data and a profile-based climatology. J Geophys Res 109:C12003, doi:10.1029/2004 JC002378

Devassy VP, Bhattathiri PMA, Qasim SZ (1978) Trichodesmium phenomenon. Indian J Mar Sci 7:168-186

$>$ DiTullio GR, Hutchins DA, Bruland KW (1993) Interaction of iron and major nutrients controls phytoplankton growth and species composition in the tropical North Pacific Ocean. Limnol Oceanogr 38:495-508

Duce RA, LaRoche J, Altieri K, Arrigo KR and others (2008) Impacts of atmospheric anthropogenic nitrogen on the open ocean. Science 320:893-897

> Dutkiewicz S, Follows MJ, Parekh P (2005) Interactions of the iron and phosphorus cycles: a three-dimensional model study. Global Biogeochem Cycles 19:GB1021, doi:10.1029/ 2004GB002342

Eppley RW, Peterson BJ (1979) Particulate organic matter flux and planktonic new production in the deep ocean. Nature 282:677-680

Eppley RW, Renger EH (1974) Nitrogen assimilation of an oceanic diatom in nitrogen-limited continuous culture. J Phycol 10:15-23

- Eppley RW, Renger EH, Venrick EL, Mullin MM (1973) A study of plankton dynamics and nutrient cycling in the central gyre of the North Pacific Ocean. Limnol Oceanogr 18:534-551

Falkowski PG (1995) Ironing out what controls primary production in the nutrient rich waters of the open ocean. Glob Change Biol 1:161-163

Falkowski PG (1997) Evolution of the nitrogen cycle and its influence on the biological sequestration of $\mathrm{CO}_{2}$ in the ocean. Nature 387:272-276

Fitzwater SE, Coale KH, Gordon RM, Johnson KS, Ondrusek ME (1996) Iron deficiency and phytoplankton growth in the equatorial Pacific. Deep-Sea Res II 43:995-1015 
Fu F, Zhang Y, Bell PRF, Hutchins DA (2005) Phosphate uptake and growth kinetics of Trichodesmium (cyanobacteria) isolates from the North Atlantic Ocean and the Great Barrier Reef, Australia. J Phycol 41:62-73

Gnanadesikan A, Sarmiento LJ, Slater RD (2003) Effects of patchy ocean fertilization on atmospheric carbon dioxide and biological production. Global Biogeochem Cycles 17: 1050

Gordon RM, Coale KH, Johnson KS (1997) Iron distributions in the equatorial Pacific: implications for new production. Limnol Oceanogr 42:419-431

Gordon RM, Johnson KS, Coale KH (1998) The behaviour of iron and other trace elements during the IronEx-I and PlumEx experiments in the equatorial Pacific. Deep-Sea Res II 45:995-1041

Gruber N (2008) The marine nitrogen cycle: overview of distributions and processes. In: Capone DG, Bronk DA, Mulholland MR, Carpenter EJ (eds) Nitrogen in the marine environment, 2nd edn. Elsevier, Amsterdam, p 1-50

Harrison DP (2007) Ocean Nourishment ${ }^{\mathrm{TM}}$ in the Philippines-proof of concept report for the Sulu Sea. EOS-REP-07-008 Rev E, Earth Ocean \& Space, Sydney. Available at www.earthoceanspace.com/pages/products/ product. php?idArticle $=7845$

Jin X, Gruber N (2003) Offsetting the radiative benefit of ocean iron fertilization by enhancing $\mathrm{N}_{2} \mathrm{O}$ emissions. Geophys Res Lett 30:2249, doi:10.1029/2003GL018458

Johnson KS, Gordon RM, Coale KH (1997) What controls dissolved iron concentration in the world ocean? Mar Chem 57:137-161

Johnston P, Santillo D, Stringer R, Parmentier R, Hare B, Krueger M (1999) Ocean disposal/sequestration of carbon dioxide from fossil fuel production and use: an overview of rationale, techniques and implications. Technical Note 01/99 Greenpeace Research Laboratories, Exeter

Jones ISF (1996) Enhanced carbon dioxide uptake by the world's oceans. Energy Convers Manag 37:1049-1052

Jones ISF (2001) The global impact of ocean nourishment. Proc 1st Nat Conf on Carbon Sequestration, Washington, DC, 14-17 May 2001. US Dept Energy — National Energy Technology Laboratory, Pittsburgh, PA. Available at www.netl.doe.gov/publications/proceedings/01/carbon seq/6b2.pdf

> Jones ISF, Otaegui D (1997) Photosynthetic greenhouse gas mitigation by ocean nourishment. Energy Convers Manag 38:S367-S372

> Jones ISF, Young HE (2009) The potential of the ocean for the management of global warming. Int J Global Warming 1: $43-56$

Judd B, Harrison DP, Jones ISF (2008) Engineering ocean nourishment. Proc World Congr Eng 2008, Vol II, 2-4 July 2008, London, UK, p 1315-1319. Available at http://hdl. handle.net/2123/2664

Klausmeier CA, Litchman E, Daufresne T, Levin SA (2008) Phytoplankton stoichiometry. Ecol Res 23:479-485

> Laws EA, Falkowski PG, Smith WO, Ducklow H, McCarthy JJ (2000) Temperature effects on export production in the open ocean. Global Biogeochem Cycles 14:1231-1246

Lenton TM, Vaughan NE (2009) The radiative forcing potential of different climate geoengineering options. Atmos Chem Phys 9:5539-5561

Letelier RM, Karl DM (1996) Role of Trichodesmium spp. in the productivity of the subtropical North Pacific Ocean. Mar Ecol Prog Ser 133:263-273

Levitus S, Boyer TP, Antonov J (1994) World ocean atlas 1994. Vol 5. Interannual variability of upper ocean thermal structure. Tech Rep PB-95-270120/XAB;NOAA-ATLAS-5. NESDIS, Washington, DC
Lovelock JE, Rapley CG (2007) Ocean pipes could help the Earth to cure itself. Nature 449:403

Mahaffey C, Michaels AF, Capone DG (2005) The conundrum of marine $\mathrm{N}_{2}$ fixation. Am J Sci 305:546-595

Mahowald NM, Engelstaedter S, Luo C, Sealy A and others (2009) Atmospheric iron deposition: global distribution, variability, and human perturbations. Annu Rev Mar Sci $1: 245-278$

> Marinov I, Fellows M, Gnanadesikan A, Sarmiento JL, Slater RD (2008) How does ocean biology affect atmospheric $\mathrm{pCO}_{2}$ ? Theory and models. J Geophys Res 113:C07032, doi:10.1029/2007JC04598

Markels M Jr (2002) Method of sequestering carbon dioxide with a fertilizer comprising chelated iron. United States Patent 6440367, available at www.freepatentsonline.com/ 6440367.html

Markels M Jr, Barber RT (2001) Sequestration of $\mathrm{CO}_{2}$ by ocean fertilization. Proc 1st Nat Conf on Carbon Sequestration, Washington, DC, 14-17 May 2001. US Dept Energy - National Energy Technology Laboratory, Pittsburgh, PA. Available at www.netl.doe.gov/publications/ proceedings/01/ carbon_seq/p25.pdf

> Martin JH (1990) Glacial-interglacial $\mathrm{CO}_{2}$ change: the iron hypothesis. Paleoceanography 5:1-13

> Martin JH, Fitzwater SE, Gordon RM (1990a) Iron deficiency limits phytoplankton growth in Antarctic waters. Global Biogeochem Cycles 4:5-12

Martin JH, Gordon RM, Fitzwater SE (1990b) Iron in Antarctic waters. Nature 345:156-158

Martin JH, Gordon RM, Fitzwater SE (1991) The case for iron. Limnol Oceanogr 36:1793-1802

Martin JH, Coale KH, Johnson KS, Fitzwater SE and others (1994) Testing the iron hypothesis in ecosystems of the equatorial Pacific Ocean. Nature 371:123-129

Matear RJ, Elliott B (2004) Enhancement of oceanic uptake of anthropogenic $\mathrm{CO}_{2}$ by macronutrient fertilisation. J Geophys Res 109:C04001, doi:10.1029/2007 JC000321

> Matsumoto K (2007) Radiocarbon-based circulation age of the world ocean. J Geophys Res 112:C09004, doi:10.1029/ 2007JC004095

Menzel DW, Ryther JH (1961) Nutrients limiting the production of phytoplankton in the Sargasso Sea, with special reference to iron. Deep-Sea Res 7:276-281

Michaels AF, Silver MW (1988) Primary production, sinking fluxes and the microbial food web. Deep-Sea Res Part A 35:473-490

Michaels AF, Olson D, Sarmiento JL, Ammerman JW and others (1996) Inputs, losses and transformations of nitrogen and phosphorus in the pelagic North Atlantic Ocean. Biogeochemistry 35:181-226

> Mulholland MR (2007) The fate of nitrogen fixed by diazotrophs in the ocean. Biogeosciences 4:37-51

> Najjar RG, Jin X, Louanchi F, Aumont O and others (2007) Impact of circulation on export production, dissolved organic matter, and dissolved oxygen in the ocean: results from phase II of the Ocean Carbon-Cycle Model Intercomparison Project (OCMIP-2). Global Biogeochem Cycles 21:GB3007, doi:10.1029/2006GB002857

Needoba JA, Foster RA, Sakamota C, Zehr JP, Johnson KS (2007) Nitrogen fixation by unicellular diazotrohic cyanobacteria in the temporate oligotrophic North Pacific Ocean. Limnol Oceanogr 52:1317-1327

Orr JC, Aumont O (1999) Exploring the capacity of the ocean to retain artificially sequestered $\mathrm{CO}_{2}$. In: Riemer R, Eliasson B, Wokaun A (eds) Greenhouse gas control technologies. Elsevier, Amsterdam, p 281-286 
Paerl HW, Crocker KM, Prufert LE (1987) Limitation of $\mathrm{N}_{2}$ fixation in coastal marine waters: relative importance of molybdenum, iron, phosphorus and organic matter availability. Limnol Oceanogr 32:525-536

Painter SC, Sanders R, Waldron HN, Lucas ML, Torres-Valdes $S$ (2008) Urea distribution and uptake in the Atlantic Ocean between $50^{\circ} \mathrm{N}$ and $50^{\circ} \mathrm{S}$. Mar Ecol Prog Ser 368: $53-63$

Parekh P, Follows MJ, Boyle E (2004) Modeling the global ocean iron cycle. Global Biogeochem Cycles 18:GB1002, doi:10.1029/2003GB00206

Parekh P, Follows MJ, Boyle E (2005) Decoupling of iron and phosphate in the global ocean. Global Biogeochem Cycles 19:GB2020, doi:10.1029/2004GB002280

Pauly D, Christensen V, Froese R, Palomares ML (2000) Fishing down aquatic food webs. Am Sci 88:46-51

Plattner GK, Gruber N, Frenzel H, Williams JC (2005) Decoupling marine export production from new production. Geophys Res Lett 32:L11612, doi:10.1029/2005GL022660

Rees AP, Nightingale PD, Owens NJP, PML FeeP Team (2007) FeeP - An in situ $\mathrm{PO}_{4}{ }^{3-}$ and $\mathrm{Fe}^{2+}$ addition experiment to waters of the sub-tropical north-east Atlantic. Geophys Res Abstr 9:01440

Sambrotto RN, Mace BJ (2000) Coupling of biological and physical regimes across the Antarctic Polar Front as reflected by nitrogen production and recycling. Deep-Sea Res II 47:3339-3368

Sañudo-Wilhelmy SA, Kustka AB, Gobler CJ, Hutchins DA and others (2001) Phosphorus limitation of nitrogen fixation by Trichodesmium in the central Atlantic Ocean. Nature 411:66-69

Sarmiento JL, Gruber N (2006) Ocean biogeochemical dynamics. Princeton University Press, Princeton, NJ

Schmidt M, Hutchins DA (1999) Size-fractionated biological iron and carbon uptake along coastal to offshore transect in the NE Pacific. Deep-Sea Res II 46:2487-2503

Shephard IG (2009) Geoengineering the climate: science, governance and uncertainty. Royal Society, London

Shoji K, Jones ISF (2001) The costing of carbon credits from ocean nourishment plants. Sci Total Environ 277:27-31

Smythe-Wright D, Boswell SM, Breithaupt P, Davidson RD, Dimmer CH, Eiras Diaz LB (2006) Methyl iodide production in the ocean: implications for climate change. Global Biogeochem Cycles 20:GB3003, doi:10.1029/2005 GB002642

Subramaniam A, Yager PL, Carpenter EJ, Mahaffey C and others (2008) Amazon River enhances diazotrophy and carbon sequestration in the tropical North Atlantic Ocean. Proc Natl Acad Sci USA 105:10460-10465

Takeda S, Tsuda A (2005) An in situ iron-enriched experiment in the western subarctic Pacific (SEEDS): introduction and summary. Prog Oceanogr 64:95-109

Thingstad TF, Krom MD, Mantoura RFC, Flaten GAF and others (2005) Nature of phosphorus limitation in the

Editorial responsibility: Hans Heinrich Janssen,

Oldendorf/Luhe, Germany ultraoligotrophic eastern Mediterranean. Science 309: 1068-1071

Thomas WH (1969) Phytoplankton nutrient enrichment experiments off Baja California and in the eastern equatorial Pacific Ocean. J Fish Res Board Can 26:1133-1145

Toyota T, Nakashima T, Fujita T, Ishii S (1991) Surface sea water fertilization experiment with deep water. In: Hirano $\mathrm{T}$ (ed) Study of the development of an effective technique to utillise deep sea water resources. Japan Science and Technology Agency, Research and Development Bureau, Tokyo

Tranter DJ, Newell BS (1968) Enrichment experiments in the Indian Ocean. Deep-Sea Res 10:1-9

Trick CG, Bill BD, Cochlan WP, Wells ML, Trainer VL, Pickell LD (2010) Iron enrichment stimulates toxic diatom production in high-nitrate, low-chlorophyll areas. Proc Natl Acad Sci USA 107:5887-5892

Trull T, Rintoul SR, Hadfield M, Abraham ER (2001) Circulation and seasonal evolution of polar waters south of Australia: implications for iron fertilization of the Southern Ocean. Deep-Sea Res II 48:2439-2466

Tsuda A, Takeda S, Saito H, Nishioka J and others (2003) A mesoscale iron enrichment in the Western Subarctic Pacific induces a large centric diatom bloom. Science 300:958-961

Tsuda A, Takeda S, Saito H, Nishioka J and others (2007) Evidence for the grazing hypothesis: grazing reduces plankton response of the HNLC ecosystem to iron enrichment in the Western Subarctic Pacific (SEEDS II). J Oceanogr 63: 983-994

> Turner SM, Nightingale PD, Spokes LJ, Liddicoat MI, Liss PS (1996) Increased dimethyl sulphide concentrations in sea water from in situ iron enrichment. Nature 383:513-517

Tyrrell T (1999) The relative influences of nitrogen and phosphorus on oceanic primary production. Nature 400:525-531

> Yamasaki A (2003) An overview of $\mathrm{CO}_{2}$ mitigation options for global warming-emphasizing $\mathrm{CO}_{2}$ sequestration options. J Chem Eng of Jpn 36:361-375

Yool A, Martin AP, Fernandez C, Clark DR (2007) The significance of nitrification for oceanic new production. Nature 447:999-1002

Zehr JP, Waterbury JB, Turner PJ, Montoya JP (2001) Unicellular cyanobacteria fix $\mathrm{N}_{2}$ in the subtropical North Pacific Ocean. Nature 412:635-638

> Zeldis J (2001) Mesozooplankton community composition, feeding and export production during SOIREE. Deep-Sea Res II 48:2615-2634

Zeebe RE, Archer D (2005) Feasibility of ocean fertilization and its impact on future atmospheric $\mathrm{CO}_{2}$ levels. Geophys Res Lett 32:L109703, doi:10.1029/2005GL022449

Zettler ER, Olson RJ, Binder BJ, Chisholm SW, Fitzwater SE, Gordon RM (1996) Iron-enrichment bottle experiments in the equatorial Pacific: responses of individual phytoplankton cells. Deep-Sea Res II 43:1017-1029

Submitted: December 8, 2009; Accepted: October 18, 2010 Proofs received from author(s): February 25, 2011 